\title{
Oxidative Stress in Graves Disease and Graves Orbitopathy
}

\author{
Giulia Lanzolla Claudio Marcocci Michele Marinò \\ Endocrinology Unit II, Department of Clinical and Experimental Medicine, University of Pisa and \\ University Hospital of Pisa, Pisa, Italy
}

\section{Keywords}

Graves hyperthyroidism · Graves orbitopathy · Oxidative stress · Reactive oxygen species · Selenium

\begin{abstract}
Oxidative stress is involved in the pathogenesis of Graves hyperthyroidism (GH) and Graves orbitopathy (GO) and an antioxidant approach has been proposed for both. In $\mathrm{GH}$, a disbalance of the cell redox state is associated with thyroid hyperfunction and antithyroid medications may reduce oxidative stress. Tissue hypoxia participates in the pathogenesis of $\mathrm{GO}$, and oxygen free radicals are involved in the typical changes of orbital tissues as reported by in vitro and clinical studies. Antioxidant agents, especially selenium, have been proposed as a therapeutic option for GH and GO. A clinical study regarding the use of selenium in mild GO has provided evidence for a beneficial effect in the short term, even though its beneficial effects in the long term are still to be investigated. In addition to selenium, a protective role of other antioxidant agents, i.e., quercetin, enalapril, vitamin $\mathrm{C}, \mathrm{N}$-acetyl-L-cysteine and melatonin has been suggested by in vitro studies, although clinical studies are lacking. Here, we review the role of oxidative stress and antioxidant agents in $\mathrm{GH}$ and GO.

(c) 2020 European Thyroid Association Published by S. Karger AG, Basel
\end{abstract}

\section{Introduction}

Graves disease (GD) is a common autoimmune disease, with a prevalence of $\sim 1 \%$ [1]. Although GD affects primarily the thyroid, extrathyroidal manifestations, i.e., Graves orbitopathy (GO), pretibial myxoedema, and acropachy [2-5], can be observed. Graves hyperthyroidism $(\mathrm{GH})$ is due to autoantibodies against the thyroid-stimulating hormone receptor (TSH-R), which bind to the TSH-R, leading to thyrocyte proliferation and hyperfunction [6]. However, the etiopathogenesis is likely multifactorial, and the complex pathogenetic interplay includes, among others, oxidative stress $[4,6]$.

GO is observed in $~ 25-30 \%$ of GH patients, making it the most common extrathyroidal manifestation of GD [7]. The pathogenesis of GO is autoimmune due to both humoral and cellular immunity against the TSH-R and possibly other autoantigens expressed by thyrocytes and orbital fibroblasts (OFs). The ultimate pathogenetic mechanisms are not completely clear, but the most popular hypothesis is that autoreactive T lymphocytes infiltrate orbital tissues, triggering, together with autoantibodies, the release of inflammatory agents, including chemokines, cytokines, growth factors, and oxygen reactive species, resulting in fibroblast proliferation, differentiation into adipocytes, and enhanced release of glycosami- 
noglycans, especially hyaluronic acid (HA) $[1,6]$. The process ultimately results in orbital fat expansion and extraocular muscle enlargement, the orbital remodeling typical of GO. Oxidative stress plays an important role in the pathogenesis of GO. In this regard, a number of antioxidant agents, among which are selenium and selenoproteins, have been proposed to have a therapeutic action. In addition, statins (3-hydroxy-3-methylglutarylcoenzyme reductase inhibitors), because of their anti-oxidative actions, might also be considered for GO treatment [6].

\section{Oxidative Stress in GH}

The balance of the cell redox state is a key point in cellular homeostasis. Reactive oxygen species (ROS), including hydrogen peroxide $\left(\mathrm{H}_{2} \mathrm{O}_{2}\right)$, hydroxyl radicals $\left(\mathrm{OH}^{\circ}\right)$, lipid peroxides, and superoxide anions $\left(\mathrm{O}^{2}\right)$, are characterized by the presence of unpaired electrons, making them highly charged. ROS interfere with intracellular functions, thereby damaging various cellular components $[7,8]$. Under physiological conditions, antioxidant agents, such as glutathione peroxidase (GPX), superoxide dismutase (SOD), catalase, and glutathione (GSH), act as ROS antagonists, therefore balancing the cell redox state [7-9].

Thyrotoxicosis is a hypermetabolic state characterized by saturation of the physiological antioxidant systems due to the high consumption of intracellular ATP and oxygen as well as to dysfunction of the mitochondrial respiratory chain, which promote the production of ROS in peripheral tissues and in the thyroid [7-10]. Thus, oxidative stress may exert a dual action in GH. On the one hand, it may damage peripheral tissues contributing the clinical manifestation of hyperthyroidism. On the other hand, it may damage thyroid cells, which may worsen the autoimmune reaction by exposing autoantigens to the immune system.

Studies in animal models suggest that thyrotoxicosis promotes oxidative stress as well as the response of the physiological antioxidant machinery $[11,12]$. In hyperthyroid rats, the administration of vitamin $\mathrm{E}$, a potent inhibitor of lipid peroxidation and oxidative stress, reduces plasma malondialdehyde (MDA), a marker of lipid peroxidation, as well as the antioxidant agents SOD and GPX $[11,12]$. Moreover, vitamin E seems to be protective also against a thyroxine-induced increase in lipid peroxidation in cardiac and skeletal muscles [9]. The most relevant studies on oxidative stress in thyroid diseases in humans have been conducted in GH patients either with uncontrolled hyperthyroidism or after recovering of a euthyroid state with antithyroid drugs (ATD) or radioiodine [1318]. In patients with untreated hyperthyroidism, the levels of oxidative stress parameters in serum, plasma, and erythrocytes were higher than in euthyroid subjects [1318]. ATD reduce the levels of oxidative stress markers due to restoration of euthyroidism and possibly to their antioxidant properties $[13-15,17]$. The evaluation of the antioxidant defense system in thyrotoxic patients resulted in conflicting findings $[13,14,18,19]$. Komosinska-Vassev et al. [19] reported an increase in erythrocyte SOD, $\mathrm{CAT}$, and GPX in patients with GH compared to agematched controls, without differences in serum GSH reductase (an antioxidant enzyme involved in GSH synthesis), and in the total antioxidant status. Bednarek et al. [14] found an increase in plasma SOD and catalase in patients with GH of short duration (1-2 months) compared to healthy subjects, but not of GPX and GSH reductase, which were instead decreased. Abalovich et al. [13] reported that erythrocyte SOD and catalase activities were decreased in hyperthyroid GH patients compared to controls, without differences in terms of erythrocyte GPX or plasma total reactive antioxidant potential. More recently, a reduction in the total antioxidant capacity in patients with an average duration of hyperthyroidism of $2.3 \pm 1.5$ months was found by Aslan et al. [18]. Probably, patients with hyperthyroidism of a longer duration have exhausted their antioxidant defense system, which explains the decreased cellular and serum antioxidant activities [20, $21]$. It has been also reported that the monoclonal thyroid-stimulating antibody M22 and polyclonal serum thyroid-stimulating antibodies (TSAb) from GH patients promote ROS generation and lipid peroxidation [22].

\section{Oxidative Stress in GO}

Oxidative stress is defined as a disruption of the balance between ROS production and elimination, which causes remarkable damage to several cellular components, i.e., proteins, lipids, membranes, and nucleic acids, ultimately resulting in mitochondrial dysfunction and a loss of enzymatic activity $[23,24]$. A number of laboratory studies support a pathogenetic role of ROS in GO [20-22, 25-31]. In 1992 it was shown that $\mathrm{H}_{2} \mathrm{O}_{2}$, which induces oxidative stress, promotes the expression of heat shock protein 72 (HSP-72) in GO fibroblasts, with HSP-72 being involved in T-lymphocyte activation as well as in interleukin (IL)-1 $\beta$ release and glycosaminoglycan accumulation 
Table 1. Antioxidant agents in GH and GO: laboratory studies

\begin{tabular}{|c|c|c|c|}
\hline Reference & Fibroblast source & Compound & Main finding \\
\hline $\begin{array}{l}\text { Lisi et al. } \\
\text { [59] }\end{array}$ & $\begin{array}{l}\text { Orbital tissue from } 5 \mathrm{GO} \\
\text { patients } \\
\text { Normal orbital tissue } \\
\text { from } 5 \text { patients who } \\
\text { underwent eye surgery } \\
\text { for unrelated reasons }\end{array}$ & $\begin{array}{l}\text { Quercetin } \\
\text { Cells were incubated with quercetin or, as } \\
\text { controls with quercitrin or rutin } \\
\text { Cell proliferation, cell necrosis, apoptosis, and } \\
\text { HA were measured }\end{array}$ & $\begin{array}{l}\text { Reduction of cell proliferation and HA release in GO fibroblasts: } \\
\text { quercetin, but not rutin or quercitrin, reduced cell proliferation, } \\
\text { with no difference between GO and control fibroblasts; the effect } \\
\text { of quercetin on proliferation was due to necrosis and cell cycle } \\
\text { blockade, whereas apoptosis was unaffected; quercetin reduced HA } \\
\text { in the cell media, with no difference between GO and control } \\
\text { fibroblasts }\end{array}$ \\
\hline $\begin{array}{l}\text { Tsai et al. } \\
{[46]}\end{array}$ & $\begin{array}{l}\text { Orbital tissue from } 7 \mathrm{GO} \\
\text { patients } \\
\text { Normal orbital tissue } \\
\text { from } 5 \text { patients who } \\
\text { received surgery for } \\
\text { noninflammatory } \\
\text { conditions }\end{array}$ & $\begin{array}{l}\mathrm{N} \text {-acetylcysteine } \\
\text { or vitamin C } \\
\text { Cells were treated with various } \mathrm{H}_{2} \mathrm{O}_{2} \\
\text { concentrations or pretreated with } \\
N \text {-acetylcysteine or vitamin } \mathrm{C} \text {, followed by } \\
\text { treatment with } \mathrm{H}_{2} \mathrm{O}_{2} \\
\text { Cell proliferation, cell necrosis, apoptosis, and } \\
\text { HA production were measured }\end{array}$ & $\begin{array}{l}\text { Reduction of proliferation and release of cytokines in GO } \\
\text { fibroblasts: when GO fibroblasts were exposed to } \mathrm{H}_{2} \mathrm{O}_{2} \text { at a } \\
\text { concentration of } 50 \mu \mathrm{M} \text { or above, cytotoxicity was observed; lower } \\
\text { concentrations of } \mathrm{H}_{2} \mathrm{O}_{2}(3.125-25 \mu \mathrm{M}) \text { increased the survival of } \\
\text { GO fibroblasts; this biphasic effect was not found in control } \\
\text { fibroblasts; } 6.25 \mu \mathrm{M} \mathrm{H}_{2} \mathrm{O}_{2} \text { led to an increase in TGF- } \beta_{1} \text {, IL-1 } 1 \beta \text {, and } \\
\text { superoxide anion in } \mathrm{GO} \text { fibroblasts but not in control fibroblasts; } \\
\text { pretreatment with } N \text {-acetylcysteine or vitamin C reversed the } \\
\text { enhanced proliferation and the production of TGF- } \beta_{1} \text {, IL-1 } 1 \beta \text {, and } \\
\text { superoxide anion of GO fibroblasts }\end{array}$ \\
\hline
\end{tabular}

\section{Botta et al. Orbital tissue from 5 GO Enalapril}

[60] patients

Normal orbital tissue from 5 patients who underwent eye surgery for unrelated reasons
Fibroblasts were treated with enalapril or as a control, with lisinopril

Cell proliferation, lactate dehydrogenase release (as a measure of cell necrosis), apoptosis, and $\mathrm{HA}$ in the cell media were measured
Reduction of cell proliferation and $\mathrm{HA}$ release in $\mathrm{GO}$ fibroblasts: the proliferation of OF was reduced in both GO and control fibroblasts by enalapril; because enalapril did not affect necrosis or apoptosis, the effects on proliferation probably reflected an inhibition of cell growth and/or a delay in the cell cycle; enalapril reduced $\mathrm{HA}$ in the media from both $\mathrm{GO}$ and control fibroblasts Lisinopril had negligible effects

\section{Rotondo Orbital adipose tissue} Dottore from 6 GO patients

et al. [47] Normal orbital tissue from 6 patients who underwent eye surgery for unrelated conditions

\section{Selenium}

To induce oxidative stress, cells were incubated with $\mathrm{H}_{2} \mathrm{O}_{2}$ at various concentrations; to assess the effects of selenium, cells were preincubated with medium without compounds or with medium containing selenium (SeMCys hydrochloride) or MCys Cell proliferation, HA, and pro-inflammatory cytokines production were measured

\section{Rotondo Orbital adipose tissue} Dottore from 6 GO patients et al. [58] Normal orbital tissue from 6 patients who underwent eye surgery for unrelated conditions

\section{Selenium}

Cells were incubated with $\mathrm{H}_{2} \mathrm{O}_{2}$ at $50 \mu \mathrm{M}$

To assess the effects of selenium, cells were preincubated with medium without compounds or with medium containing SeMCys or, as a control, MCys

Cell vitality, lactate dehydrogenase production (as a measure of cell necrosis), and apoptosis were measured

\begin{tabular}{|c|c|c|}
\hline $\begin{array}{l}\text { Rotondo } \\
\text { Dottore } \\
\text { et al. [61] }\end{array}$ & $\begin{array}{l}\text { Orbital adipose tissue } \\
\text { from } 6 \mathrm{GO} \text { patients } \\
\text { Normal orbital tissue } \\
\text { from } 6 \text { patients who } \\
\text { underwent eye surgery } \\
\text { for unrelated conditions }\end{array}$ & $\begin{array}{l}\text { Vitamin C, N-acetyl-cysteine, and melatonin } \\
\text { Cells were treated with } \mathrm{H}_{2} \mathrm{O}_{2} \text { to induce } \\
\text { oxidative stress; cell vitality assays were } \\
\text { performed to determine the noncytotoxic dose } \\
\text { of each antioxidant; the following assays were } \\
\text { performed: GSSG, cell proliferation, HA, } \\
\text { TNF- } \alpha \text {, IFN- } \gamma \text {, and IL- } 1 \beta\end{array}$ \\
\hline
\end{tabular}

Rotondo Orbital adipose tissue Dottore from $6 \mathrm{GO}$ patients et al. [67] Normal orbital tissue from 6 patients who underwent eye surgery for unrelated conditions

\section{Retinol, $\boldsymbol{\beta}$-carotene, and vitamin $\mathrm{E}$} Oxidative stress was induced by incubation with $\mathrm{H}_{2} \mathrm{O}_{2}$; to assess the effects of the various antioxidant agents, cells were preincubated with complete medium without compounds or with medium containing either one of the compounds at various concentrations GSSG, cell proliferation, hyaluronic acid, TNF- $\alpha$, IFN- $\gamma$, and IL- $1 \beta$ were measured
Reduction of proliferation, release of $\mathrm{HA}$ and cytokines in GO fibroblasts: $\mathrm{H}_{2} \mathrm{O}_{2}$ induced an increase in cell GSSG (a marker of oxidative stress) and fibroblast proliferation, which were reduced by selenium; $\mathrm{H}_{2} \mathrm{O}_{2}$ promoted production of the cytokines involved in the response to oxidative stress, i.e., TNF- $\alpha$, IL1- $\beta$, and IFN- $\gamma$; the increase in TNF- $\alpha$ and IFN- $\gamma$ was rescued by selenium; the effects of selenium were similar in GO and control fibroblasts concerning oxidative stress and cytokines, i.e., they were exclusive to GO fibroblasts concerning proliferation and HA

Reduction of cell damage in GO fibroblasts: SeMCys, rescued from $\mathrm{H}_{2} \mathrm{O}_{2}$-dependent cytotoxicity, by reducing necrosis and apoptosis, with no difference between GO and control fibroblasts; MCys had no effect; $\mathrm{H}_{2} \mathrm{O}_{2}$ determined a significant increase in GSSG, which was counteracted by SeMCys, but not by MCys, with no differences between GO and control fibroblasts

Reduction of cell proliferation and $\mathrm{HA}$ release in $\mathrm{GO}$ fibroblasts: all of the 3 antioxidant agents reduced $\mathrm{H}_{2} \mathrm{O}_{2}$-dependent oxidative stress; vitamin $\mathrm{C}$ reduced proliferation in $\mathrm{GO}$ but not in control fibroblasts. $N$-acetyl-L-cysteine reduced proliferation and IFN- $\gamma$ in GO, and HA and IL- $1 \beta$ in both GO and control fibroblasts; melatonin reduced IL1 $\beta$ and HA in GO and control fibroblasts, and IFN- $\gamma$ only in GO fibroblasts

Reduction of cell proliferation in GO fibroblasts: all of the 3 antioxidants reduced the increase in GSSG induced by $\mathrm{H}_{2} \mathrm{O}_{2}$ in GO but not in control fibroblasts; $\beta$-carotene reduced the increased proliferation induced by $\mathrm{H}_{2} \mathrm{O}_{2}$ in $\mathrm{GO}$ but not in control fibroblasts, whereas retinol and vitamin $\mathrm{E}$ had no effect; IL- $1 \beta$ was reduced by all 3 substances; retinol reduced IFN- $\gamma$ in GO and control fibroblasts 
Table 2. Antioxidant agents in GH and GO: clinical studies

\begin{tabular}{|c|c|c|c|c|}
\hline Reference & Type of study & Compound and dosage & Patients & Main finding \\
\hline $\begin{array}{l}\text { Bouzas } \\
\text { et al. [42] }\end{array}$ & $\begin{array}{l}\text { Prospective } \\
\text { non-randomized } \\
\text { placebo-controlled, } \\
\text { clinical trial }\end{array}$ & $\begin{array}{l}\text { Allopurinol } \\
\text { (300 mg daily orally) and } \\
\text { nicotinamide } \\
\text { ( } 300 \text { mg daily orally) } \\
\text { vs. placebo for } 3 \text { months }\end{array}$ & $\begin{array}{l}22 \text { patients with } \\
\text { mild or moderately } \\
\text { severe, active, newly } \\
\text { diagnosed GO }\end{array}$ & $\begin{array}{l}\text { Beneficial effect in mild and moderately severe GO: } \\
9(82 \%) \text { of } 11 \text { patients treated with oral antioxidants } \\
\text { showed improvement of GO vs. } 3(27 \%) \text { of } 11 \\
\text { patients in the control group }(p<0.05) \text {. } \\
\text { Soft tissue inflammation was the component of the } \\
\text { disease that responded more to treatment }\end{array}$ \\
\hline $\begin{array}{l}\text { Marcocci } \\
\text { et al. [40] }\end{array}$ & $\begin{array}{l}\text { Prospective, } \\
\text { multicenter, } \\
\text { randomized, } \\
\text { double-blind, } \\
\text { placebo-controlled } \\
\text { clinical trial }\end{array}$ & $\begin{array}{l}\text { Sodium selenite } \\
\text { ( } 100 \mu \mathrm{g} \text { twice daily orally), or } \\
\text { pentoxifylline } \\
\text { ( } 600 \mathrm{mg} \text { twice daily orally) } \\
\text { vs. placebo (twice daily) } \\
\text { for } 6 \text { months }\end{array}$ & $\begin{array}{l}159 \text { patients with } \\
\text { mild GO }\end{array}$ & $\begin{array}{l}\text { Beneficial effect of selenium in mild GO: at the } \\
6 \text {-month evaluation, treatment with selenium, but not } \\
\text { with pentoxifylline, was associated with an improved } \\
\text { quality of life }(p<0.001) \text { as well as in a reduced eye } \\
\text { involvement }(p=0.01) \text { and slowed progression of GO } \\
(p=0.01) \text {, as compared with placebo }\end{array}$ \\
\hline $\begin{array}{l}\text { Vrca } \\
\text { et al. [43] }\end{array}$ & $\begin{array}{l}\text { Prospective, } \\
\text { randomized, } \\
\text { placebo-controlled, } \\
\text { clinical trial }\end{array}$ & $\begin{array}{l}\text { Methimazole plus an additional } \\
\text { capsule daily of a fixed combination } \\
\text { of antioxidants containing } \\
\beta \text {-carotene }(6 \mathrm{mg}) \text {, selenium }(60 \mu \mathrm{g}) \text {, } \\
\text { vitamins } \mathrm{C}(200 \mathrm{mg}) \text { and } \mathrm{E}(36 \mathrm{mg}) \\
\text { vs. methimazole alone }\end{array}$ & $\begin{array}{l}55 \text { patients with } \\
\text { newly detected GH }\end{array}$ & $\begin{array}{l}\text { Better control of hyperthyroidism: faster } \\
\text { normalization of thyroid hormones in patients with } \\
\text { GH treated with methimazole plus the mixture of } \\
\text { antioxidant agents compared with control group }\end{array}$ \\
\hline $\begin{array}{l}\text { Calissendorff } \\
\text { et al. [45] }\end{array}$ & $\begin{array}{l}\text { Prospective, } \\
\text { randomized, } \\
\text { placebo-controlled, } \\
\text { clinical trial }\end{array}$ & $\begin{array}{l}\text { "Block and replace" treatment with } \\
\text { methimazole and levothyroxine, plus } \\
\text { selenium ( } 200 \mu \text { g daily orally) } \\
\text { vs. "block and replace treatment" } \\
\text { alone for } 9 \text { months }\end{array}$ & $\begin{array}{l}38 \text { patients, with } \\
\text { newly diagnosed } \\
\text { and untreated } \mathrm{GH}\end{array}$ & $\begin{array}{l}\text { Better control of hyperthyroidism in } \mathrm{GH} \text { : FT } 4 \\
\text { decreased more in the selenium group at } 18 \text { weeks ( } 14 \\
\text { vs. } 17 \text { pmol/L compared to the placebo group, } p= \\
0.01) \text { and also at } 36 \text { weeks ( } 15 \text { vs. } 18 \text { pmol/L, } p= \\
0.01 \text { ). TSH increased more in the selenium group at } \\
18 \text { weeks }(0.05 \text { vs. } 0.02 \mathrm{mIU} / \mathrm{L}, p=0.04)\end{array}$ \\
\hline $\begin{array}{l}\text { Leo } \\
\text { et al. [38] }\end{array}$ & $\begin{array}{l}\text { Prospective, } \\
\text { randomized, } \\
\text { placebo-controlled, } \\
\text { clinical trial }\end{array}$ & $\begin{array}{l}\text { Methimazole plus } \\
\text { L-selenomethionine ( } 166 \mu \mathrm{g} \text { daily } \\
\text { orally) vs. methimazole alone for } \\
3 \text { months }\end{array}$ & $\begin{array}{l}30 \text { patients with } \\
\text { untreated } \mathrm{GH}\end{array}$ & $\begin{array}{l}\text { No beneficial effect of selenium in the short-term } \\
\text { control of GH: Administration of Methimazole was } \\
\text { followed by a reduction of FT3 and FT4, with no } \\
\text { difference between groups }\end{array}$ \\
\hline $\begin{array}{l}\text { Kahaly } \\
\text { et al. [44] }\end{array}$ & $\begin{array}{l}\text { Prospective, } \\
\text { randomized, } \\
\text { double-blind, } \\
\text { placebo-controlled, } \\
\text { clinical trial }\end{array}$ & $\begin{array}{l}\text { Methimazole plus sodium } \\
\text { selenite ( } 300 \mu \text { g daily orally) vs. } \\
\text { methimazole alone for } 6 \text { months }\end{array}$ & $\begin{array}{l}61 \text { patients with } \\
\text { untreated } \mathrm{GH}\end{array}$ & $\begin{array}{l}\text { No beneficial effect of selenium in GH: a response } \\
\text { was observed in } 25 \text { of } 31 \text { patients ( } 80 \%) \text { and in } 27 \text { of } \\
33(82 \%) \text { at week } 24 \text { in the selenium (+methimazole) } \\
\text { and placebo (+methimazole) groups, respectively. } \\
\text { During a } 12 \text {-week follow-up, } 11 \text { of } 23(48 \%) \text { and } 12 \text { of } \\
27 \text { ( } 44 \%) \text { relapsed in the selenium and placebo } \\
\text { groups, respectively. Serum concentrations of } \\
\text { selenium and selenoprotein P were unrelated to } \\
\text { response or recurrence rates }\end{array}$ \\
\hline
\end{tabular}

$[25,28]$. In addition, the effects of $\mathrm{H}_{2} \mathrm{O}_{2}$ were reduced by antioxidative agents or ATD [25]. Burch et al. [26] demonstrated oxidative damage in vivo in orbital tissues from patients with GO, as well as an increased proliferation of GO OFs induced by superoxides. The hypothesis that oxidative stress promotes cell proliferation and the release of cytokines was also suggested by recent, additional studies, in which higher levels of $\mathrm{H}_{2} \mathrm{O}_{2}$ and of SOD activity, as well as decreased GPX activity and a reduced GSH/oxidized GSH ratio, were found in GO OFs [28-31].

In addition to basic studies (Table 1) the importance of oxidative stress in GO is supported by clinical evidence (Table 2). Cigarette smoking, by enhancing in vitro generation of ROS and reducing the antioxidant machinery, is the most important environmental risk factor for GO [32]. In addition, patients with recent-onset GH, regardless of the presence of GO, have higher plasma levels of SOD and catalase than control subjects [16]. However, normalization of oxidative markers after restoration of euthyroidism was found only in patients without GO, suggesting that orbital inflammation contributes to the increased serum markers of oxidative stress [13-15]. Tsai et al. $[29,30]$ found higher urinary levels of 8 -hydroxy-2'deoxyguanosine (8-OHdG), a marker of oxidative DNA damage, in patients with active GO. Furthermore, the urinary levels of 8-OHdG were reduced by glucocorticoid (GC) treatment, which was associated with a reduction of GO activity and severity [31]. Interestingly, urinary 
8-OHdG was found to be relatively high in smokers and in patients with GO relapse [31]. In confirmation of an effect of GC on oxidative stress, Akarsu et al. [33] reported a positive correlation between the GO clinical activity score and MDA, as well as a reduction of MDA plasma levels after GC administration. Similar data were obtained by Abalovich et al. [13] and by Bednarek et al. [14] .

\section{Antioxidant Agents in GD and GO}

\section{Selenium}

The trace mineral selenium, which was first described in 1817 [34], exerts its functions as selenocysteine after incorporation into selenoproteins. GPX, thioredoxin reductases, and iodothyronine deiodinases (D1, D2, or D3) are the best known selenoproteins, all of which have antioxidant and enzymatic functions [34] and are highly expressed in the thyroid, where they contribute to maintenance of the cell reduction-oxidation balance [35]. The main dietary sources of selenium are meat, seafood, shellfish, offal, eggs, and cereals [34, 35]. The bioavailability of selenium varies because of its content in the soil for growing crops and fodder. Furthermore, other factors, such as the presence of ions complexed with selenium, soil $\mathrm{pH}$, and selenium speciation, can influence its bioavailability. After absorption in the gastrointestinal tract and transport to the liver, selenium binds to several glycoproteins, thereby forming selenoglycoproteins that reach peripheral tissues, where their concentrations are proportional to the degree of oxidative stress $[34,35]$.

Selenium status can be assessed by measuring total serum selenium concentrations or circulating selenoproteins, among which are GPX-3 and selenoprotein P [36]. Selenium status is influenced by the geographical area [34-36]. The recommended daily intake of selenium is 53 $\mu \mathrm{g}$ in women and $60 \mu \mathrm{g}$ in men, but the mean daily selenium intake is not sufficient in most European countries [34-36]. It is generally recommended to avoid selenium deficiency, but, on the other hand, selenium excess has been reported to increase the risk of type 2 diabetes or malignancies [36, 37], although the issue is still a matter of debate. In any case, it would be ideal to measure serum selenium before starting supplementation in order to avoid overdosage in subjects with baseline serum levels higher than $122 \mu \mathrm{g} / \mathrm{L}$ [36].

Selenium supplements contain sodium selenite or selenomethionine [34]. There are no differences between them until circulating selenoproteins are saturated, because selenium is mainly used for biosynthesis of seleno- proteins [38-41]. However, after saturation of selenoproteins, only selenomethionine can increase serum selenium through its incorporation into proteins, whereas selenite is excreted $[39,40]$. Consequently, the individual state of selenium mostly depends on the effect of selenite, and the use of selenomethionine as a supplement leads to a rise in selenium levels also in subjects with a sufficient selenium concentration to begin with.

\section{Use of Selenium in GH}

The effects of selenium on GH were investigated in a few clinical studies, which tested selenium either alone or within a mixture containing other antioxidant agents, in patients treated with ATD [41-47]. The hypothesis was that selenium deficiency, by worsening the counteracting response of the antioxidant machinery to ROS, could enhance oxidative stress in thyrotoxicosis. Three studies were performed using selenium alone $[38,44,45]$. In one of those studies [45], hyperthyroid, selenium-deficient patients treated with a block-and-replace regimen (methimazole plus levothyroxine) were randomized to receiving selenium $(200 \mu \mathrm{g} /$ day $)$ or placebo, resulting in a slightly better control of hyperthyroidism in the selenium group [45]. No beneficial effects on thyroid function or peripheral manifestations of hyperthyroidism were instead exerted by selenium in 2 additional randomized clinical trials conducted in $\mathrm{GH}$ patients treated with methimazole plus selenium versus no treatment $[40,44]$. Interestingly, the main difference between the first study and the subsequent 2 was the presence of a baseline selenium deficiency only in the first one, which may explain the conflicting results. There are also studies in which administration of selenium was associated with a mixture of other antioxidant agents. However, no clear-cut results were obtained $[43,48]$. Because of the available studies, in our opinion there is not sufficient evidence to recommend the addition of selenium to ATD in the management of patients with GH.

\section{Use of Selenium in GO}

The management of severe and active GO is quite well defined, and treatment options include high-dose GC, orbital irradiation, or both [49]. Over the last few years, to various extents, other medications, i.e., rituximab [50], the recently FDA-approved teprotumumab [51, 52], mycophenolate [53], and tocilizumab [54], have been proven effective. In contrast, the treatment of mild GO is typically limited to local measures [49]. However, in the natural course of mild GO, a proportion of patients $(\sim 15 \%)$ progress to the extent that specific treatment is required
Lanzolla/Marcocci/Marinò 


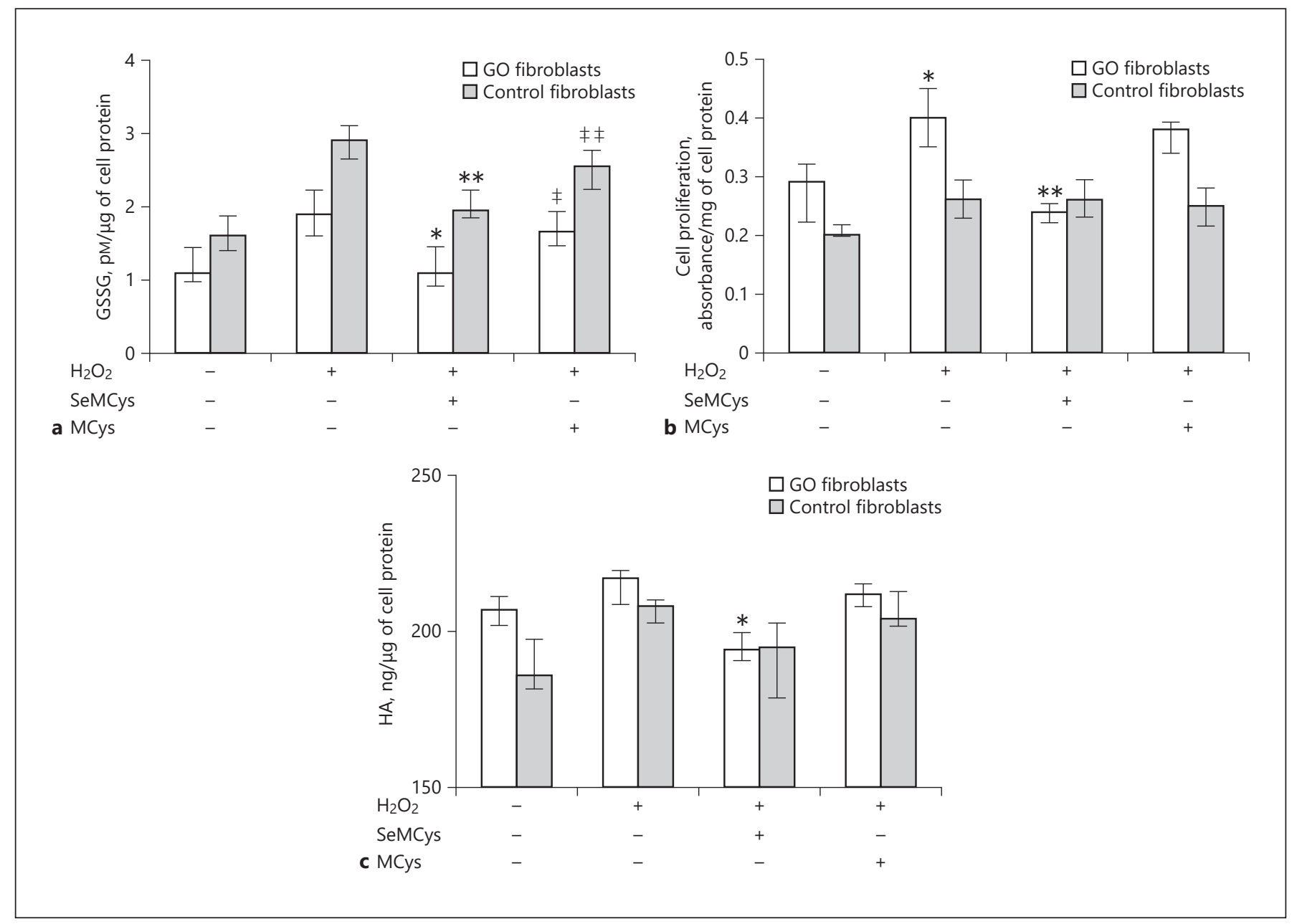

Fig. 1. a Combined effects of $\mathrm{H}_{2} \mathrm{O}_{2}(5 \mu \mathrm{mol})$, selenium $(10 \mu \mathrm{mol})$ or its control methylcysteine (MCys; $10 \mu \mathrm{mol}$ ) on GSSG in fibroblasts from patients with $\mathrm{GO}$ (GO fibroblasts) or from control subjects. ${ }^{*}$ and ${ }^{* *} p=0.02$ vs. $\mathrm{H}_{2} \mathrm{O}_{2} .{ }^{*}$ and ${ }^{*} p=$ ns vs. $\mathrm{H}_{2} \mathrm{O}_{2} \cdot p=\mathrm{ns}$ between $\mathrm{GO}$ and control fibroblasts. $\mathbf{b}$ Combined effects of $\mathrm{H}_{2} \mathrm{O}_{2}$ $(5 \mu \mathrm{mol})$, selenium $(10 \mu \mathrm{mol})$, or MCys $(10 \mu \mathrm{mol})$ on cell prolif-

$[1,4]$. Major treatments, in particular high-dose GC, are not recommended for mild GO unless there is an impairment of the quality of life which justifies the risk of GCrelated adverse events [49,55-57]. Nevertheless, most patients with mild GO complain of local symptoms and therefore demand some sort of treatment. An ideal treatment for these patients should be well tolerated, effective, widely available, and affordable. In view of the role of oxidative stress, antioxidant supplements represent a possible approach. In this regard, selenium has been investigated as a reasonable option.

Basic and clinical studies have explored the effect of selenium in GO. Beneficial effects in primary cultures of eration in $\mathrm{GO}$ and control fibroblasts. ${ }^{*} p=0.02$ vs. untreated cells. ${ }^{* *} p=0.02$ vs. $\mathrm{H}_{2} \mathrm{O}_{2} \cdot p=0.003$ between $\mathrm{GO}$ and control fibroblasts. c Combined effects of $\mathrm{H}_{2} \mathrm{O}_{2}(5 \mu \mathrm{mol})$, selenium $(10 \mu \mathrm{mol})$, or its control methilcysteine (MCys; $10 \mu \mathrm{mol}$ ) on HA release in $\mathrm{GO}$ and control fibroblasts. ${ }^{*} p=0.02$ vs. $\mathrm{H}_{2} \mathrm{O}_{2} . p=0.02$ between $\mathrm{GO}$ and control fibroblasts [47].

GO OFs were provided in 2 separate studies $[47,58]$. In a first study [47], GSH disulfide (GSSG), GPX activity, cell proliferation, $\mathrm{HA}$ and proinflammatory cytokines were measured in $\mathrm{OF}$ after treatment with low-dose $\mathrm{H}_{2} \mathrm{O}_{2}$, which induces oxidative stress, in the presence or absence of selenium-(methyl)-selenocysteine (SeMCys). SeMCys reduced oxidative stress, cell proliferation (Fig. 1), and HA synthesis in OFs from both GO patients and control subjects. The observation that selenium acts in GO and control OFs should not, however, represent a contraindication for the clinical use of selenium. Thus, normal fibroblasts, unlike GO fibroblasts, are not subjected to oxidative stress and selenium has only minimal actions un- 


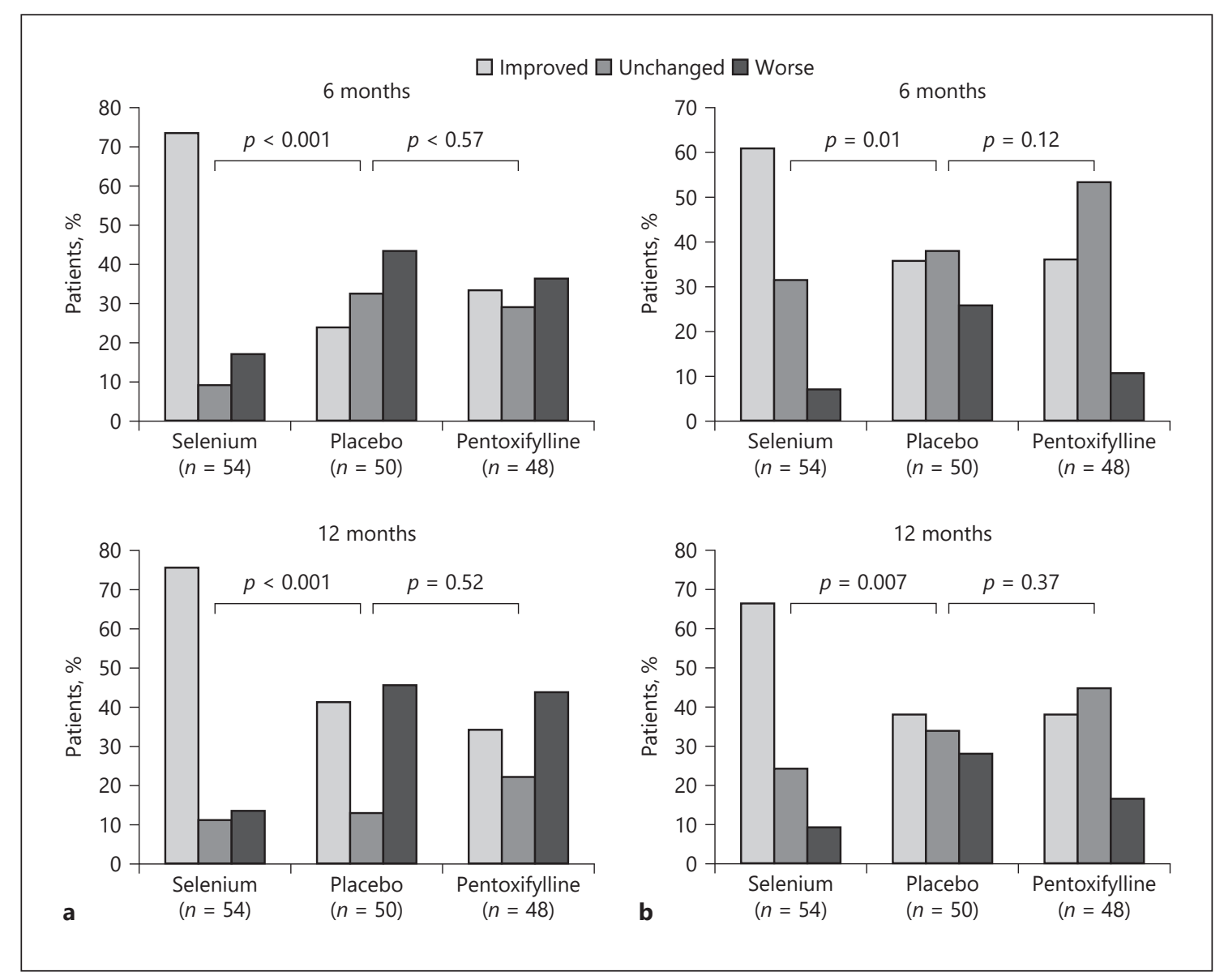

Fig. 2. a GO-specific quality-of-life questionnaire (GO-QOL) at 6 and 12 months in patients with mild GO treated with selenium, placebo, or pentoxifylline. b GO outcome at 6 and 12 months based on a composite ophthalmological score [40].

der physiological conditions, as shown by experiments on cell vitality [47].

In a subsequent study, the same authors observed that $\mathrm{H}_{2} \mathrm{O}_{2}$ seems to have a dual effect on cell proliferation, depending on the dose used [58]. Thus, high concentrations of $\mathrm{H}_{2} \mathrm{O}_{2}$ promoted a progressive decrease in cell vitality and an obvious reduction of cell proliferation, whereas low concentrations increased cell proliferation. Interestingly, the effects of both high-and low-dose $\mathrm{H}_{2} \mathrm{O}_{2}$ were inhibited by SeMCys. Although $\mathrm{H}_{2} \mathrm{O}_{2}$ did not affect $\mathrm{HA}$ release, SeMCys counteracted HA synthesis in GO but not in control fibroblasts, suggesting that selenium may act on HA release, at least in part, regardless of the oxidative stress induced by $\mathrm{H}_{2} \mathrm{O}_{2}$, through mechanisms that are still to be cleared.

The first clinical pilot study on antioxidants showed an improvement in GO soft tissue involvement in patients given allopurinol plus nicotinamide [42]. After these promising results, an antioxidant approach was investigated further using selenium and pentoxifylline. Thus, the European Group on Graves Orbitopathy (EUGOGO) conducted a placebo-controlled, multicenter clinical trial in Europe [40] in countries with a mild selenium deficiency. One hundred fifty-nine patients with mild GO were randomized to receiving selenium (sodium selenite at $100 \mu \mathrm{g}$ twice/day, equivalent to $91.3 \mu \mathrm{g}$ of selenium), pentoxifylline (600 mg twice/day), or placebo (twice/day) for a period of 6 months, followed by a 6-month followup period [40]. At 6 months, treatment with selenium, unlike treatment with pentoxifylline, compared with placebo, was associated with an improvement in the quality of life and overall eye involvement and a slowdown of GO progression (Fig. 2). A limitation of this study is that baseline selenium concentrations were not measured, and it is therefore not possible to conclude that the effectiveness of selenium was related to a possible initial deficiency. 


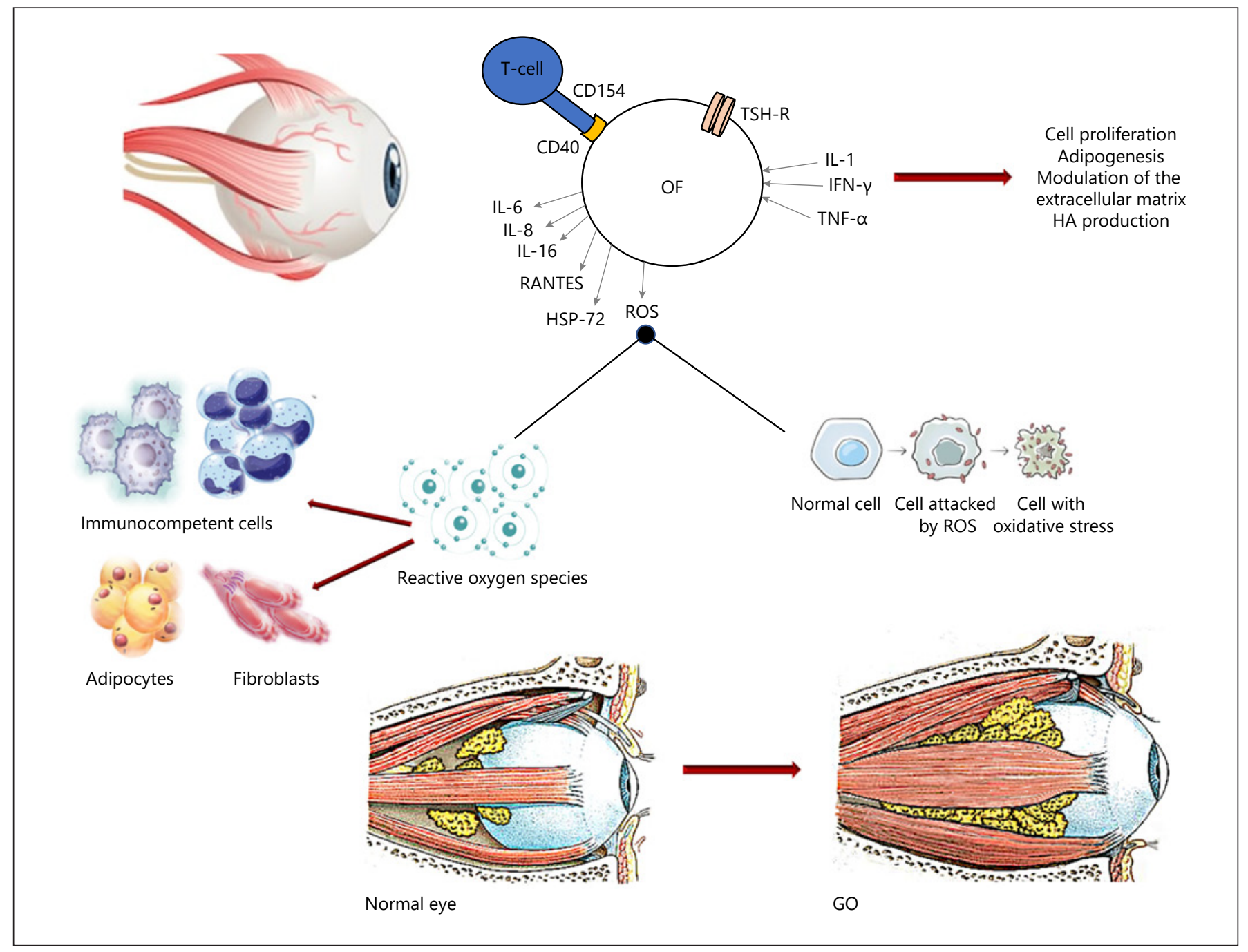

Fig. 3. Overview of the mechanisms involved in the action of oxidative stress in the pathogenesis of GO. The mechanisms that lead to the development of GO are triggered by the activation of helper $\mathrm{T}$ cells recognizing thyrotropin hormone receptor (TSHR) peptides presented by CD34+/CD40+ OF and the binding of TSHR on these cells by TRAb. These interactions induce the secretion of inflammatory cytokines, chemokines, and ROS and enhanced HA production and adipogenesis in OF. The resulting connective tis- sue remodeling causes various degrees of extraocular muscle enlargement and orbital fat expansion. Oxidative stress may exert a dual action in GO, acting in immunocompetent cells as well as in $\mathrm{OF}$ and adipocytes, thereby worsening the autoimmune response and promoting fibroblast proliferation and differentiation into adipocytes, as well as the release of HA and inflammatory cytokines. TNF- $\alpha$, tumor necrosis factor- $\alpha$; RANTES, regulated on activation, normal T cell expressed and secreted.

\section{Other Antioxidant Agents}

In addition to selenium, a protective role in GO has been suggested by in vitro studies on other antioxidant agents, i.e., quercetin, enalapril, vitamin $\mathrm{C}, \mathrm{N}$-acetyl-Lcysteine, and melatonin (Table 1) [59-61].

Quercetin belongs to the flavonoid family and is commonly present in the diet, being contained in vegetables and fruit [59]. Quercetin has anti-inflammatory, antioxidant, and antiviral activities, and it is also capable of in- ducing apoptosis in tumor cells [62]. In addition, quercetin blocks the transforming growth factor (TGF)- $\beta / \mathrm{Smad}$ signaling pathway, leading to inhibition of the proliferation of scar-derived fibroblasts $[63,64]$. Moreover, quercetin reduces the adipogenesis induced by cigarette smoke extract in GO fibroblasts and it has been shown to exert an antifibrotic action in GO fibroblasts and adipocytes [59]. Based on this evidence, the possibility that quercetin could reduce GO fibroblast proliferation was investigat- 
ed. A study performed using primary cultures of OFs provided evidence for an inhibitory effect of quercetin on proliferation and HA release [59]. Quercetin had a necrotic effect on OFs and blocked the cell cycle, which probably contributed the observed reduced proliferation [59]. In spite of these findings, to our knowledge, no in vivo studies have been performed.

Enalapril, a common antihypertensive medication, was reported to have inhibitory effects on fibroblast proliferation and HA production in cheloid scars $[65,66]$. Thus, a study was conducted in OFs, which were treated with enalapril or a control compound (lisinopril) [60]. A reduction of fibroblast proliferation and $\mathrm{HA}$ release was observed following enalapril treatment, in both GO and control OFs, without any effects in terms of necrosis or apoptosis [60]. Again, no clinical studies are available.

In a relatively recent study, additional antioxidants, including vitamin $\mathrm{C}, \mathrm{N}$-acetyl-L-cysteine and melatonin, were tested [61]. Vitamin C reduced proliferation in GO but not in control OFs. $\mathrm{N}$-acetyl-L-cysteine reduced fibroblast proliferation and interferon (IFN) $-\gamma$ production in GO OFs, as well as HA synthesis and IL1- $\beta$ levels in both GO and control OFs. Regarding melatonin, it reduced IL1- $\beta$ and HA production in GO and control fibroblasts and IFN- $\gamma$ only in GO fibroblasts [61]. Overall, the results support an in vitro beneficial role of vitamin $\mathrm{C}$ and $\mathrm{N}$-acetyl-L-cysteine, suggesting a possible use of these compounds in vivo. In contrast, because of the lack of effects on fibroblast proliferation, melatonin does not seem to be a strong candidate for a clinical use.

There are also additional bioavailable substances with antioxidant effects, among which $\beta$-carotene seems to be promising [67]. Thus, proliferation was found to be reduced in OFs incubated with $\beta$-carotene, which reduced tumor necrosis factor- $\alpha$, interferon- $\gamma$, and IL1- $\beta$ release, an effect that was exerted also by vitamin $\mathrm{E}$ and retinol. Once again, no clinical studies are available.

\section{Conclusions}

Balancing the cell redox state is a key point in cellular homeostasis and, as depicted in Figure 3, when disrupted, ROS interfere with intracellular reactions thereby damaging various cellular components. Oxidative stress plays an important role in both GH and GD. The management of patients with mild GO represents a challenge for endocrinologists and ophthalmologists. Studies performed so far suggest that selenium is the antioxidant agent with the most promising results, which opened its clinical use in mild GO. It is possible that selenium may have beneficial effects in moderate to severe GO, especially when patients are selenium deficient. Clearly, further studies are needed in this regard.

\section{Conflict of Interest Statement}

There is no conflict of interests.

\section{Funding Sources}

This study was not funded.

\section{Author Contributions}

G.L. contributed to the drafting this paper. C.M. and M.M. contributed to the conception and critical revision of this work.

\section{References}

1 Smith TJ, Hegedüs L. Graves' Disease. N Engl J Med. 2016 Oct;375(16):1552-65.

2 Menconi F, Marcocci C, Marinò M. Diagnosis and classification of Graves' disease. Autoimmun Rev. 2014 Apr-May;13(4-5):398-402.

3 Bartalena L, Fatourechi V. Extrathyroidal manifestations of Graves' disease: a 2014 update. J Endocrinol Invest. 2014 Aug;37(8):691-700.

4 Piantanida E, Tanda ML, Lai A, Sassi L, Bartalena L. Prevalence and natural history of Graves' orbitopathy in the XXI century. J Endocrinol Invest. 2013 Jun;36(6):444-9.

5 Marinò M, Latrofa F, Menconi F, Chiovato L, Vitti P. An update on the medical treatment of Graves' hyperthyroidism. J Endocrinol Invest. 2014 Nov;37(11):1041-8.
6 Lanzolla G, Vannucchi G, Ionni I, Campi I, Sileo F, Lazzaroni E, et al. Cholesterol serum levels and use of statins in Graves' Orbitopathy: A new starting point for the therapy. Front Endocrinol (Lausanne). 2020 Jan;10: 933.

7 Leporati P, Groppelli G, Zerbini F, Rotondi $\mathrm{M}$, Chiovato L. Etiopathogenesis of Basedow's disease. Trends and current aspects. Nucl Med (Stuttg). 2015;54(5):204-10.

8 Marinò M, Latrofa F, Menconi F, Chiovato L, Vitti P. Role of genetic and non-genetic factors in the etiology of Graves' disease. J Endocrinol Invest. 2015 Mar;38(3):283-94.
9 Asayama K, Dobashi K, Hayashibe H, Kato K Vitamin E protects against thyroxine-induced acceleration of lipid peroxidation in cardiac and skeletal muscles in rats. J Nutr Sci Vitaminol (Tokyo). 1989 Oct;35(5):407-18.

10 Wilson R, Chopra M, Bradley H, McKillop $\mathrm{JH}$, Smith WE, Thomson JA. Free radicals and Graves' disease: the effects of therapy. Clin Endocrinol (Oxf). 1989 Apr;30(4):429-33.

11 Venditti P, Balestrieri M, Di Meo S, De Leo T. Effect of thyroid state on lipid peroxidation, antioxidant defences, and susceptibility to oxidative stress in rat tissues. J Endocrinol. 1997 Oct;155(1):151-7. 
12 Yamada T, Mishima T, Sakamoto M, Sugiyama M, Matsunaga S, Wada M. Oxidation of myosin heavy chain and reduction in force production in hyperthyroid rat soleus. J Appl Physiol (1985). 2006 May;100(5):1520-6.

13 Abalovich M, Llesuy S, Gutierrez S, Repetto M. Peripheral parameters of oxidative stress in Graves' disease: the effects of methimazole and 131 iodine treatments. Clin Endocrinol (Oxf). 2003 Sep;59(3):321-7.

14 Bednarek J, Wysocki $\mathrm{H}$, Sowiński J. Oxidative stress peripheral parameters in Graves' disease: the effect of methimazole treatment in patients with and without infiltrative ophthalmopathy. Clin Biochem. 2005 Jan;38(1):13-8.

15 Rybus-Kalinowska B, Zwirska-Korczala K, Kalinowski M, Kukla M, Birkner E, Jochem J. Activity of antioxidative enzymes and concentration of malondialdehyde as oxidative status markers in women with newly diagnosed Graves-Basedow disease and after thiamazole therapy leading to euthyroidism. Pol Arch Med Wewn. 2008 Jul-Aug;118(7-8):420-5.

16 Cetinkaya A, Kurutas EB, Buyukbese MA, Kantarceken B, Bulbuloglu E. Levels of malondialdehyde and superoxide dismutase in subclinical hyperthyroidism. Mediators Inflamm. 2005 Feb;2005(1):57-9.

17 Weetman AP. Effect of the anti-thyroid drug methimazole on interleukin-1 and interleukin-2 levels in vitro. Clin Endocrinol (Oxf). 1986 Aug;25(2):133-42.

18 Aslan M, Cosar N, Celik H, Aksoy N, Dulger AC, Begenik H, et al. Evaluation of oxidative status in patients with hyperthyroidism. Endocrine. 2011 Oct;40(2):285-9.

19 Komosinska-Vassev K, Olczyk K, Kucharz EJ, Marcisz C, Winsz-Szczotka K, Kotulska A. Free radical activity and antioxidant defense mechanisms in patients with hyperthyroidism due to Graves' disease during therapy. Clin Chim Acta. 2000 Oct;300(1-2):107-17.

20 Bartalena L, Tanda ML, Piantanida E, Lai A. Oxidative stress and Graves' ophthalmopathy: in vitro studies and therapeutic implications. Biofactors. 2003;19(3-4):155-63.

21 Marcocci C, Leo M, Altea MA. Oxidative stress in graves' disease. Eur Thyroid J. 2012 Jul;1(2):80-7.

22 Diana T, Daiber A, Oelze M, Neumann S, Olivo PD, Kanitz M, et al. Stimulatory TSH-Receptor antibodies and oxidative stress in Graves' Disease. J Clin Endocrinol Metab. 2018 Oct;103(10):3668-77.

23 Daiber A, August M, Baldus S, Wendt M, Oelze M, Sydow K, et al. Measurement of NAD $(P)$ $\mathrm{H}$ oxidase-derived superoxide with the luminol analogue L-012. Free Radic Biol Med. 2004 Jan;36(1):101-11.

24 Wenzel P, Mollnau H, Oelze M, Schulz E, Wickramanayake JM, Müller J, et al. First evidence for a crosstalk between mitochondrial and NADPH oxidase-derived reactive oxygen species in nitroglycerin-triggered vascular dysfunction. Antioxid Redox Signal. 2008 Aug;10(8):1435-47.
25 Heufelder AE, Wenzel BE, Bahn RS. Methimazole and propylthiouracil inhibit the oxygen free radical-induced expression of a 72 kilodalton heat shock protein in Graves' retroocular fibroblasts. J Clin Endocrinol Metab. 1992 Apr;74(4):737-42.

26 Burch HB, Lahiri S, Bahn RS, Barnes S. Superoxide radical production stimulates retroocular fibroblast proliferation in Graves' ophthalmopathy. Exp Eye Res. 1997 Aug;65(2):3116.

27 Lu R, Wang P, Wartofsky L, Sutton BD, Zweier JL, Bahn RS, et al. Oxygen free radicals in interleukin-1beta-induced glycosaminoglycan production by retro-ocular fibroblasts from normal subjects and Graves' ophthalmopathy patients. Thyroid. 1999 Mar;9(3): 297-303.

28 Hondur A, Konuk O, Dincel AS, Bilgihan A, Unal M, Hasanreisoglu B. Oxidative stress and antioxidant activity in orbital fibroadipose tissue in Graves' ophthalmopathy. Curr Eye Res. 2008 May;33(5):421-7.

29 Tsai CC, Wu SB, Cheng CY, Kao SC, Kau HC, Chiou $\mathrm{SH}$, et al. Increased oxidative DNA damage, lipid peroxidation, and reactive oxygen species in cultured orbital fibroblasts from patients with Graves' ophthalmopathy: evidence that oxidative stress has a role in this disorder. Eye (Lond). 2010 Sep;24(9):1520-5.

30 Tsai CC, Wu SB, Cheng CY, Kao SC, Kau HC, Lee SM, et al. Increased response to oxidative stress challenge in Graves' ophthalmopathy orbital fibroblasts. Mol Vis. 2011;17:2782-8.

31 Tsai CC, Kao SC, Cheng CY, Kau HC, Hsu WM, Lee CF, et al. Oxidative stress change by systemic corticosteroid treatment among patients having active graves ophthalmopathy. Arch Ophthalmol. 2007 Dec;125(12):1652-6.

32 Wiersinga WM. Smoking and thyroid. Clin Endocrinol (Oxf). 2013 Aug;79(2):145-51.

33 Akarsu E, Buyukhatipoglu H, Aktaran S, Kurtul N. Effects of pulse methylprednisolone and oral methylprednisolone treatments on serum levels of oxidative stress markers in Graves' ophthalmopathy. Clin Endocrinol (Oxf). 2011 Jan;74(1):118-24.

34 Rayman MP. The importance of selenium to human health. Lancet. 2000 Jul;356(9225): 233-41.

35 Drutel A, Archambeaud F, Caron P. Selenium and the thyroid gland: more good news for clinicians. Clin Endocrinol (Oxf). 2013 Feb; 78(2):155-64.

36 Duntas LH. Selenium and the thyroid: a closeknit connection. J Clin Endocrinol Metab. 2010 Dec;95(12):5180-8.

37 Stranges S, Marshall JR, Natarajan R, Donahue RP, Trevisan M, Combs GF, et al. Effects of long-term selenium supplementation on the incidence of type 2 diabetes: a randomized trial. Ann Intern Med. 2007 Aug;147(4):21723.
38 Leo M, Bartalena L, Rotondo Dottore G, Piantanida E, Premoli P, Ionni I, et al. Effects of selenium on short-term control of hyperthyroidism due to Graves' disease treated with methimazole: results of a randomized clinical trial. I Endocrinol Invest. 2017 Mar;40(3): 281-7.

39 Hegedüs L, Bonnema SJ, Winther KH. Selenium in the Treatment of Thyroid Diseases: An Element in Search of the Relevant Indications? Eur Thyroid J. 2016 Sep;5(3):149-51.

40 Marcocci C, Kahaly GJ, Krassas GE, Bartalena L, Prummel M, Stahl M, et al.; European Group on Graves' Orbitopathy. Selenium and the course of mild Graves' orbitopathy. N Engl J Med. 2011 May;364(20):1920-31.

41 Marinò M, Marcocci C, Vitti P, Chiovato L, Bartalena L. Selenium in the treatment of thyroid diseases. Eur Thyroid J. 2017 Apr;6(2): 113-4.

42 Bouzas EA, Karadimas P, Mastorakos G, Koutras DA. Antioxidant agents in the treatment of Graves' ophthalmopathy. Am J Ophthalmol. 2000 May;129(5):618-22.

43 Vrca VB, Mayer L, Skreb F, Rahelić D, Marušić S. Antioxidant supplementation and serum lipids in patients with Graves' disease: effect on LDL-cholesterol. Acta Pharm. 2012 Mar;62(1):115-22.

44 Kahaly GJ, Riedl M, König J, Diana T, Schomburg L. Double-Blind, Placebo-Controlled, Randomized Trial of Selenium in Graves Hyperthyroidism. J Clin Endocrinol Metab. 2017 Nov;102(11):4333-41.

45 Calissendorff J, Mikulski E, Larsen EH, Möller M. A Prospective Investigation of Graves' Disease and Selenium: Thyroid Hormones, Auto-Antibodies and Self-Rated Symptoms. Eur Thyroid J. 2015 Jun;4(2):93-8.

46 Tsai CC, Wu SB, Kao SC, Kau HC, Lee FL, Wei YH. The protective effect of antioxidants on orbital fibroblasts from patients with Graves' ophthalmopathy in response to oxidative stress. Mol Vis. 2013 Apr;19:927-34.

47 Rotondo Dottore G, Leo M, Casini G, Latrofa F, Cestari L, Sellari-Franceschini S, et al. Antioxidant actions of selenium in orbital fibroblasts: a basis for the effects of selenium in Graves' orbitopathy. Thyroid. 2017 Feb; 27(2):271-8.

48 Guerra LN, Ríos de Molina MC, Miler EA, Moiguer S, Karner M, Burdman JA. Antioxidants and methimazole in the treatment of Graves' disease: effect on urinary malondialdehyde levels. Clin Chim Acta. 2005 Feb; 352(1-2):115-20.

49 Bartalena L, Baldeschi L, Boboridis K, Eckstein A, Kahaly GJ, Marcocci C, et al.; European Group on Graves' Orbitopathy (EUGOGO). The 2016 European Thyroid Association/European Group on Graves' Orbitopathy Guidelines for the Management of Graves' Orbitopathy. Eur Thyroid J. 2016 Mar;5(1): 9-26. 
50 Stan MN, Salvi M. MANAGEMENT OF ENDOCRINE DISEASE: rituximab therapy for Graves' orbitopathy - lessons from randomized control trials. Eur J Endocrinol. $2017 \mathrm{Feb}$; 176(2):R101-9.

51 Smith TJ, Kahaly GJ, Ezra DG, Fleming JC, Dailey RA, Tang RA, et al. Teprotumumab for thyroid-associated ophthalmopathy. N Engl J Med. 2017 May;376(18):1748-61.

52 Piantanida E, Bartalena L. Teprotumumab: a new avenue for the management of moderateto-severe and active Graves' orbitopathy? Endocrinol Invest. 2017 Aug;40(8):885-7.

53 Kahaly GJ, Riedl M, König J, Pitz S, Ponto K, Diana T, et al. Mycophenolate plus methylprednisolone versus methylprednisolone alone in active, moderate-to-severe Graves orbitopathy (MINGO): a randomised, observer-masked, multicentre trial. Lancet Diabetes Endocrinol. 2018;6:287-98.

54 Pérez-Moreiras JV, Alvarez-López A, Gómez EC. Treatment of active corticosteroid-resistant graves' orbitopathy. Ophthal Plast Reconstr Surg. 2014 Mar-Apr;30(2):162-7.

55 Sisti E, Coco B, Menconi F, Leo M, Rocchi R, Latrofa F, et al. Intravenous glucocorticoid therapy for Graves' ophthalmopathy and acute liver damage: an epidemiological study. Eur J Endocrinol. 2015 Mar;172(3):269-76.

56 Sisti E, Coco B, Menconi F, Leo M, Rocchi R, Latrofa F, et al. Age and Dose Are Major Risk Factors for Liver Damage Associated with Intravenous Glucocorticoid Pulse Therapy for Graves' Orbitopathy. Thyroid. 2015 Jul;25(7): $846-50$.
57 Marcocci C, Watt T, Altea MA, Rasmussen AK, Feldt-Rasmussen U, Orgiazzi J, et al.; European Group of Graves' Orbitopathy. Fatal and non-fatal adverse events of glucocorticoid therapy for Graves' orbitopathy: a questionnaire survey among members of the European Thyroid Association. Eur J Endocrinol. 2012 Feb;166(2):247-53.

58 Rotondo Dottore G, Chiarini R, De Gregorio M, Leo M, Casini G, Cestari L, et al. Selenium rescues orbital fibroblasts from cell death induced by hydrogen peroxide: another molecular basis for the effects of selenium in graves' orbitopathy. Endocrine. 2017 Nov;58(2):3869.

59 Lisi S, Botta R, Lemmi M, Sellari-Franceschini S, Altea MA, Sisti E, et al. Quercetin decreases proliferation of orbital fibroblasts and their release of hyaluronic acid. J Endocrinol Invest. 2011 Jul-Aug;34(7):521-7.

60 Botta R, Lisi S, Marcocci C, Sellari-Franceschini S, Rocchi R, Latrofa F, et al. Enalapril reduces proliferation and hyaluronic acid release in orbital fibroblasts. Thyroid. 2013 Jan; 23(1):92-6.

61 Rotondo Dottore G, Ionni I, Menconi F, Casini G, Sellari-Franceschini S, Nardi M, et al. Action of three bioavailable antioxidants in orbital fibroblasts from patients with Graves' orbitopathy (GO): a new frontier for GO treatment? J Endocrinol Invest. 2018 Feb; 41(2):193-201.

62 Woodman OL, Chan EC. Vascular and antioxidant actions of flavonols and flavones. Clin Exp Pharmacol Physiol. 2004 Nov;31(11): 786-90.
63 Phan TT, See P, Tran E, Nguyen TT, Chan SY, Lee ST, et al. Suppression of insulin-like growth factor signalling pathway and collagen expression in keloid-derived fibroblasts by quercetin: its therapeutic potential use in the treatment and/or prevention of keloids. Br J Dermatol. 2003 Mar;148(3):544-52.

64 Phan TT, Lim IJ, Chan SY, Tan EK, Lee ST, Longaker MT. Suppression of transforming growth factor beta/smad signaling in keloidderived fibroblasts by quercetin: implications for the treatment of excessive scars. J Trauma. 2004 Nov;57(5):1032-7.

65 Iannello S, Milazzo P, Bordonaro F, Belfiore F. Low-dose enalapril in the treatment of surgical cutaneous hypertrophic scar and keloid-two case reports and literature review. MedGenMed. 2006 Dec;8(4):60.

66 Kim S, Ohta K, Hamaguchi A, Omura T, Yukimura T, Miura K, et al. Angiotensin II type I receptor antagonist inhibits the gene expression of transforming growth factor-beta 1 and extracellular matrix in cardiac and vascular tissues of hypertensive rats. J Pharmacol Exp Ther. 1995 Apr;273(1):509-15.

67 Rotondo Dottore G, Ionni I, Menconi F, Casini G, Sellari-Franceschini S, Nardi M, et al. Antioxidant effects of $\beta$-carotene, but not of retinol and vitamin $\mathrm{E}$, in orbital fibroblasts from patients with Graves' orbitopathy (GO). J Endocrinol Invest. 2018 Jul;41(7):815-20. 